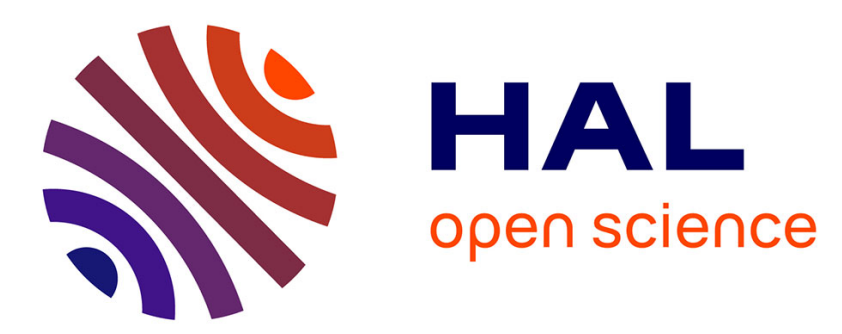

\title{
Neoliberal Rationality and Neohygienist Morality. A Foucaldian Analysis of Safe and Sustainable Urban Transport Policies in France
}

Hélène Reigner

\section{- To cite this version:}

Hélène Reigner. Neoliberal Rationality and Neohygienist Morality. A Foucaldian Analysis of Safe and Sustainable Urban Transport Policies in France. Territory, Politics, Governance, 2016, 4 (2), pp.196-215. 10.1080/21622671.2015.1123647 . hal-01630572

\section{HAL Id: hal-01630572 \\ https://hal.science/hal-01630572}

Submitted on 24 Aug 2018

HAL is a multi-disciplinary open access archive for the deposit and dissemination of scientific research documents, whether they are published or not. The documents may come from teaching and research institutions in France or abroad, or from public or private research centers.
L'archive ouverte pluridisciplinaire HAL, est destinée au dépôt et à la diffusion de documents scientifiques de niveau recherche, publiés ou non, émanant des établissements d'enseignement et de recherche français ou étrangers, des laboratoires publics ou privés. 


\section{Neoliberal Rationality and Neohygienist Morality. A Foucaldian Analysis of Safe and Sustainable Urban Transport Policies in France}

\section{HéLène Reigner}

To cite this article: HéLène Reigner (2016): Neoliberal Rationality and Neohygienist Morality. A Foucaldian Analysis of Safe and Sustainable Urban Transport Policies in France, Territory, Politics, Governance, DOI: 10.1080/21622671.2015.1123647

To link to this article: http://dx.doi.org/10.1080/21622671.2015.1123647

曲 Published online: 02 Mar 2016.

Submit your article to this journal $\pi$

Џll Article views: 2

Q View related articles $\triangle$

View Crossmark data $\nearrow$ 


\title{
Neoliberal Rationality and Neohygienist Morality. A Foucaldian Analysis of Safe and Sustainable Urban Transport Policies in France
}

\author{
HÉLÈNE REIGNER
}

(Received November 2013: in revised form October 2015)

\begin{abstract}
This article proposes to use Foucaldian analysis frameworks to inform us about neoliberalization, not so much from the viewpoint of political economics as in terms of the governance of individual behaviours. This theoretical ambition is based on the empirical analysis of contemporary policies in favour of safe, sustainable mobility in France. Characterized by the emphasis placed on users' individual responsibility and their capacity to adopt economically rational behaviours on the one hand and by powerful moral injunctions for them to adopt the 'right' safe, healthy, sustainable behaviours on the other, a neoliberal and neohygienist rationality feeds these public policies. Legitimated by 'noble causes' and depoliticized, these policies give a powerful organization of traffic in the city whose social challenges are evaded. The use of morality works as a powerful democratic anesthetic that dissolves any objection. An examination of Safe and Sustainable Urban Transport Policies testifies to the renewed subtle, diffuse mechanisms of domination based on free compliance and consent.
\end{abstract}

RÉsumé Cet article propose de mobiliser des cadres d'analyse foucaldiens pour renseigner la néolibéralisation, non pas tant sous l'angle de l'économie politique, mais comme gouvernement des conduites individuelles. Cette ambition théorique s'appuie sur l'analyse empirique des politiques contemporaines en faveur de la mobilité sûre et durable en France. Caractérisée par la mise en avant de la responsabilité individuelle des usagers et leur capacité à adopter des comportements économiquement rationnels d'une part, et par de puissantes injonctions morales à ce qu'ils adoptent de «bons » comportements sûrs, sains et durables d'autre part, une rationalité néolibérale et néohygiéniste irrigue ces politiques publiques. Légitimées par de "nobles causes » et dépolitisées, ces politiques organisent de puissantes mises en ordre des circulations dans la ville dont les enjeux sociaux sont éludés. Le recours à la morale agit comme un puissant anesthésiant démocratique qui vient dissoudre les prises de la contestation. L'examen des politiques en faveur de la mobilité sûre et durable témoigne de mécanismes renouvelés, subtils et diffus de domination fondés sur la libre-conformation et le consentement.

Exтracto En este artículo proponemos utilizar un análisis de marco foucaultiano para que nos aporte información sobre la neoliberalización, no tanto desde el punto de vista de la economía política sino más bien en términos de la gobernanza de las conductas individuales. Esta ambición teórica se basa en el análisis empírico de las políticas contemporáneas a favor de una movilidad segura y sostenible en Francia. Caracterizada, por una parte, por el énfasis puesto en la responsabilidad individual de los usuarios y su capacidad para adoptar comportamientos económicamente racionales y, por otra, por los poderosos mandatos morales para que adopten las 'correctas' conductas seguras, sanas y sostenibles, una racionalidad neoliberal y neohigienista alimenta estas

Author details: Hélène Reigner, Institut d’Urbanisme et d'Aménagement Régional, LIEU (EA 889), 2Aix-Marseille Université, 3, avenue R. Schumann, 13628 Aix en Provence Cedex 01, Marseille, France. Email: helene. reigner@univ-amu.fr 
políticas públicas. Estas políticas, legitimadas por 'causas nobles' y despolitizadas, proporcionan una influyente organización del tráfico en la ciudad mientras sus retos sociales se evaden. El uso de la moralidad funciona como un potente anestético democrático que disuelve cualquier objeción. Un examen de las políticas del transporte urbano seguro y sostenible demuestra los renovados mecanismos discretos y difusos de la dominación basada en el libre cumplimiento y consentimiento.

摘要 本文计画运用傅柯的分析架构来告知我们对新自由主义的认识，该架构并非从 政治经济学的观点, 而是就个人行为的治理进行分析。此一理论企图, 是根据对法国 当代侧重安全与可持续能动性的政策所进行的经验分析。新自由主义与新卫生主义理 性, 一方面以强调使用者的个人责任及其採纳经济理性行为的能力为特徵, 另一方面 对其注入强而有力的道德训育以接受 “正确的” 安全、健康、可持续行为并以此为特 徵, 因而深化了上述的公共政策。这些政策因 “高贵的动机” 而受到合理化、且是去政 治化的, 并赋予城市中的交通一种强大的组织, 而其社会挑战则受到回避。能动性的 运用, 作为消解任何反对异议的强力民主美学。对 “安全及可持续城市运输政策” 进行 检视，证实了根据自主顺从与合意的復廷的微妙、扩散的支配机制。

KeYwORDS governmentality urban policy mobility neoliberalism urban governance sustainable development

\section{INTRODUCTION}

Is the analytical framework of neoliberalization adequate to the study of the evolution of French urban policies? This paper claims that French urban policies, which were thought to be protected by a strong Weberian model of bureaucracy and the Welfare State, are not immune to a neoliberal rationality.

Such an undertaking immediately puts our work at the heart of contemporary scientific controversies between works that mainly mobilize comparative political economy approaches, which see a confrontation between Anglo-American academic fields and continental European Scholars. ${ }^{1}$ In a word, radical neo-Marxist works emphasize systems of domination in cities, submission to the market, and putting at a distance the supernumeraries of capitalism in the dual and revanchist city (PECK and TICKell, 2002; Brenner, 2004; Sassen, 2009; Smith, 1996), while neo-Weberian or neo-institutionalist inspired works insist on the varieties of capitalism, the pluralism of interests in the city and the political capacity of local societies to produce urban policies which are sensitive to the issues of social cohesion and the limits of a dual vision of society (STORPER and Scott, 2006; Lorrain, 2002; Le Galès, 2003; Kazepov, 2005; Pinson, 2009; Préteceille, 2009).

In this article, we propose to 'sidestep' these approaches and to view neoliberalization not from the viewpoint of political economics, but rather as a new set of 'arts of governing', a new form of governmentality and a new rationality that have penetrated every sphere of social life. How can we characterize neoliberal rationality within this Foucaldian perspective? Studies that stress a Foucaldian approach insist on three points. Firstly, neoliberal rationality is seen in the extension and dissemination of market values to all sectors of public action and to all institutions (DARDOT and LAVAL, 2009). Secondly, neoliberalism is a government of subjects that is used to regulate behaviours so that they are aligned on a model of perfectly rational economic behaviour (BROwN, 2007). Lastly, neoliberalism is an active policy put forward by public actors (the State, local authorities, etc.) which institute the market and competition and 'reprogramme' their instruments by and for neoliberal rationality (HiвоU, 2012).

Defined in this way, neoliberal rationality affects citizenship by subjecting every aspect of social life to economic calculations. Citizen-individuals are pushed to 
behave as calculating beings through a set of public policy tools (incentives or penalties) that encourage them to align themselves with economically rational behaviours. Neoliberal rationality transforms citizens into customer-individuals or entrepreneur-individuals who are responsible for their choices and therefore for their living conditions. This neoliberal rationality even contributes to a process of deactivation of democracy when 'citizens are nothing more than rational economic actors in all areas of existence', when 'citizenship, reduced to the capacity to take care of oneself, lacks any orientation toward the common good' (BROwn, 2007, p. 98, 100).

This neoliberal rationality appears to be characterized by another strong trend towards extending moralization to social life. For Brown, the significance of the arguments mobilizing the morality register is the corollary, the indispensable complement, to a neoliberal rationality that promotes individualization and extends the individual freedom to make rational choices to all spheres of society (2007). Moral justification regulates and limits individuals' freedom of choice.

This moralization can take on many forms of expression. Based on the American context, Brown has taken an interest in reaffirming the traditional moral values put forward by neo-conservative movements. This author also asserts that this moralistic temptation in politics can take on various forms that should be studied according to national contexts. She calls for international comparative research to characterize the moral economics of neoliberalism.

This field of research is precisely what we aim to contribute to here. If Christian neo-conservatism is the American translation of the moralization of social and political life in the neoliberal era, what are the moral elements behind neoliberal rationality in France?

This article is the product of qualitative research undertaken since the middle of the 2000's in the field of Safe and Sustainable Urban Transport Policies (ReIgner, 2005, 2012, 2013; ReIGNER et al., 2013). We have sought to characterize how these public policies are framed, to identify the arguments used to justify them and, lastly, to pinpoint the public policy instruments deployed to implement them.

After presenting elements in the method and investigation ('Methodological') section, the second section shows how safe, sustainable mobility policies mobilize registers of individual responsibility and rational choice, just as they use teaching and communication to shape city-dwellers' mobility behaviours. The third section shows how this neoliberal rationality is closely combined with neohygienist moral injunctions. 'Noble causes' such as health, sustainability and safety are called upon to categorize 'good' and 'bad' citizens. The fourth section proposes to explain the diffusion of this neohygienist rationality by defending the idea that bringing conducts into good order, calling upon morality and the de-politicization that are behind this rationality make it possible to move beyond and dissolve certain contradictions in the way the contemporary capitalist city works. In conclusion, we go back over what this use of morality does to democracy.

\section{METHODOLOGICAL SECTION}

Privileging a Foucaldian approach to neoliberalization poses methodological problems. Indeed, how should we grasp this neoliberal political rationality? How do we identify this 'governmentality', this government of subjects imposing behavioural norms on individuals and groups? For Michel Foucault, it is illusory to attempt to identify the actors and places of power bearing this objective insofar as the making of the obedient subject is the result of diffuse mechanisms by which authority is constantly exercised 
around and on the individual. This new governmentality is not only identified in the political field, it is not reserved to any one party - many forces are at work. In the analysis by Brown, as for Foucault, this political rationality is not related to a handful of actors or a few identified groups. Quite the contrary, this governmentality takes shape based on a mix of objects, texts, actors and techniques. Neoliberal rationality is diffused through 'a patchwork of assemblies of agents, ideas and remedies' shaped by national heritage and contexts (JEANPIERRE, 2007, p. 26), by constellations of interests and a certain contingency in their arrangement (HiвоU, 2012).

To characterize their neoliberal and neohygenist rationalities, this paper deals with the framing of Sustainable Urban Transport Policies as well as with their effective territorial implementation. In a context of urban sprawl, growing automobile traffic and increasing public concern for air quality and the quality of urban life, the French State has encouraged $^{2}$ and then required ${ }^{3}$ cities to develop Urban Mobility Plans (Plans de Déplacements Urbains - PDU). These PDUs reveal and design the desired sustainable city, the ideal future that the urban actors would like to achieve in organizing mobility in the city. These Urban Mobility Plans provide an opportunity for urban government to project a desirable future on the ground (layout of tram lines, the perimeter of semi-pedestrian areas, hubs, etc.) as well as to promote changes in people's travel behaviour. That is why the area of urban transport and travel policies provides a good field for grasping neoliberal rationality. Moreover, these urban planning documents must follow a citizen consultation procedure called a public hearing. Consequently, to draw up PDUs, many documents are produced by cities for the general public in order to explain and justify the choices and priorities of urban transport and travel policies. These communication documents give access to the arguments put forward to justify the priorities set for urban planning while the planning document as such, which is more technical, gives details of the instruments mobilized. We gathered and analysed these two categories of documents in 30 French urban areas with more than 200,000 inhabitants to understand both the framing and the spatial implementation of these policies. In-depth analysis was carried out in three cities (Grenoble, Aix en Provence and Aubagne) to perfect the results obtained. The spatialization of these policies and its legitimation was at the core of our survey. Firstly, for each town, the existing transportation network was mapped (motorways, ring roads, large feeders roads, lines of force of the mobility plan, car parks and park-and-ride facilities, major thoroughfares of the public transport network and principal interchanges). Secondly, we located all PDU's planned projects on this mapping of existing transportation networks. This was used to draw up the ideal traffic organization model that the actors would like to achieve. Placed side-by-side, the mapping of projects put forward by the representatives of towns, seemingly sparse at first glance, gives rise to a consistent, though implicit, model of urban transport planning. Thirdly, we interviewed local actors involved in these policies (elected officials and local civil servants), presenting them our maps and this generic model of the organization of traffic flows in the city. Finally, qualitative treatments of these interviews (approximately 10 in each city) as well as the communication documents on PDU's allowed us to identify a standardized justification and legitimation of these policies. While these public policies come under the responsibility of urban governments, they are also influenced by the State (especially by the Ministry for Ecology, sustainable development and Energy). That is why we also focused on national communication campaigns promoting safe and sustainable mobility. A wide sample of this type of documents has also been collected. 


\section{THE NEOLIBERAL RATIONALITY OF SAFE AND SUSTAINABLE URBAN TRANSPORT POLICIES}

The emphasis placed on individual responsibility in the framing of public issues is a strong trend that affects contemporary debates and contemporary public spaces (FRANCoIs and Neveu, 1999), in which citizens are considered as responsible for their own fate and, consequently, structural inequalities are depoliticized so that they can be interpreted as careless or irresponsible individual choices (GARAPON, 2008; BRAWLEY, 2009). Concretely, this leads to the growing importance given to 'educational' communication tools which are sometimes all that public policy consists of. This tendency is particularly visible in the transport and travel policies that manage sustainable mobility issues, with actions that are oriented towards educating citizens who are expected to adopt rational urban behaviour in their modal choices.

\section{Rational choice and individual responsibility in the management of sustainable mobility issues}

This framing of public issues, which largely favours the economic calculations of rational individuals, is particularly clear in policies that encourage the use alternative transport modes rather than the automobile. These policies are based on the principle of free modal choice. This principle gives rise to incentives for using alternative transport modes to the automobile by combining improved travel offers (improving public transport services by extending networks and/or better service frequencies, pedestrian and cycling layouts, often in the most central parts of cities) and especially by the implementation of pricing tools that discourage automobile use (expanding perimeters and increasing parking prices, installing urban toll systems, ${ }^{4}$ increasing fines, increasing the probability of being punished). These policies therefore seek to change mobility behaviours by focusing on the economic calculations that rational individuals will make. The concept of modal shift is put to work to assess these public policies' ability to 'take market share' from automobile travel. We should point out that the relevance of this choice paradigm has been questioned by many academic studies. Reasoning in terms of free modal choice could lead to evading the social challenges of mobility in city traffic flows. Sustainable mobility policies that focus on individuals to 'limit the place of the automobile in the city' and to 'fight against the all-pervasiveness of the automobile' without a more comprehensive questioning of the function of mobility in city traffic flows are increasingly criticized by academic studies perceiving the challenge of mobility as a social challenge that will tend to become increasingly acute (SHELLER and URRY, 2006; JAFFE et al., 2012). We will come back to this in the last section of this article.

Thus, through their behaviour and choices, individuals are considered as being the source of problems (air pollution, road insecurity, traffic congestion, etc.) while holding the keys to solving these problems. This leads to the growing importance given to pedagogical communication policies oriented towards educating citizens who are expected to adopt good civic urban behaviour.

Communication and education in the management of sustainable mobility issues

A consensus exists among the actors involved in contemporary transport and travel policies in favour of sustainable mobility: 'we have to communicate!' The successes and failures of public action may be attributed to the quality of communication with citizens and users. While the importance placed on communication is not unique to this field of public action (NEVEU, 2001), we must recognize that it holds a central position. 
This abundant institutional communication can be analysed to identify constants in terms of both form (graphics, colours and iconography) and substance (the arguments used, their sequencing, writing style and slogans). These documents are highly standardized. They strongly mobilize the educational register. In France, this use of 'education' in the political discourse has been growing since the 1990s. The educational imperative no longer just targets young people, but rather society as a whole to deal with a wide variety of subjects (PAUTARD, 2015).

The educational imperative involves both childish guidance and wilful submission. Childish guidance when this public pedagogy aims at increasing awareness among individuals as to their responsibility for environmental problems and orienting their behaviour so that they become 'eco-mobile' and 'eco-responsible' citizens, 'actors in sustainable mobility' (Figure 1). General mobilization for doing 'little things' is constant in these educationally targeted communication documents that assert, for example, that

the responsibility that every one of us has lies in our ability to change our behaviors. It is unquestionably the sum of all these virtuous attitudes that will turn around the trends observed and bring down toxic $\mathrm{CO}_{2}$ emissions or other greenhouse gas emissions into the air. (Figure 1)

The work behind designing these educational messages, delegated to communication professionals, mobilizes childlike imagery with a didactic, guilt-inducing tone. Wilful submission when good practices and exemplary behaviours are stressed, combined with types of persuasion that apply marketing and social psychology techniques to the consumer-citizen (green games and other educational kits including game boards, Figure 2).

We are therefore indeed dealing with forms of management far from individual practices (Foucault, 1994). Pedagogical communication plays a role in training citizen-customer-consumers ready to accept a degree of governance and authority. The educational imperative permeates the communication strategies used to convince

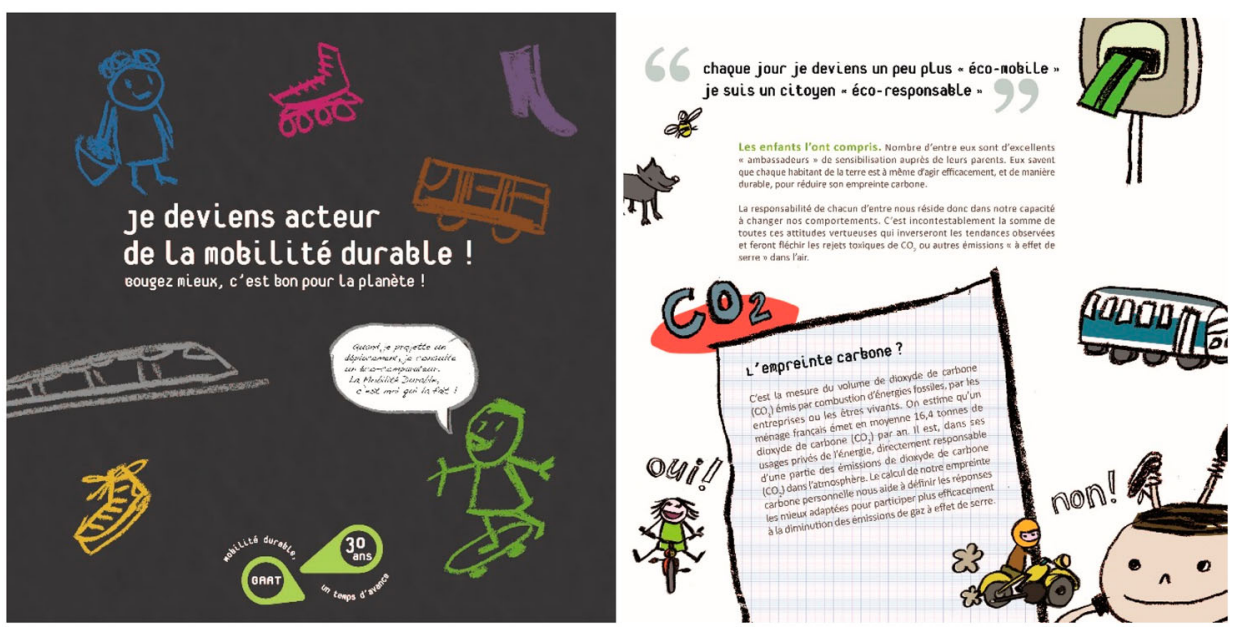

Fig. 1. The pedagogical style of communication in the management of sustainable mobility issues. Source: Groupement des Autorités Responsables des Transports, 2010, Je deviens acteur de la mobilité durable (I'm becoming a player for sustainable mobility), educational brochure, http:// www.gart.org, p. 1, 3. 

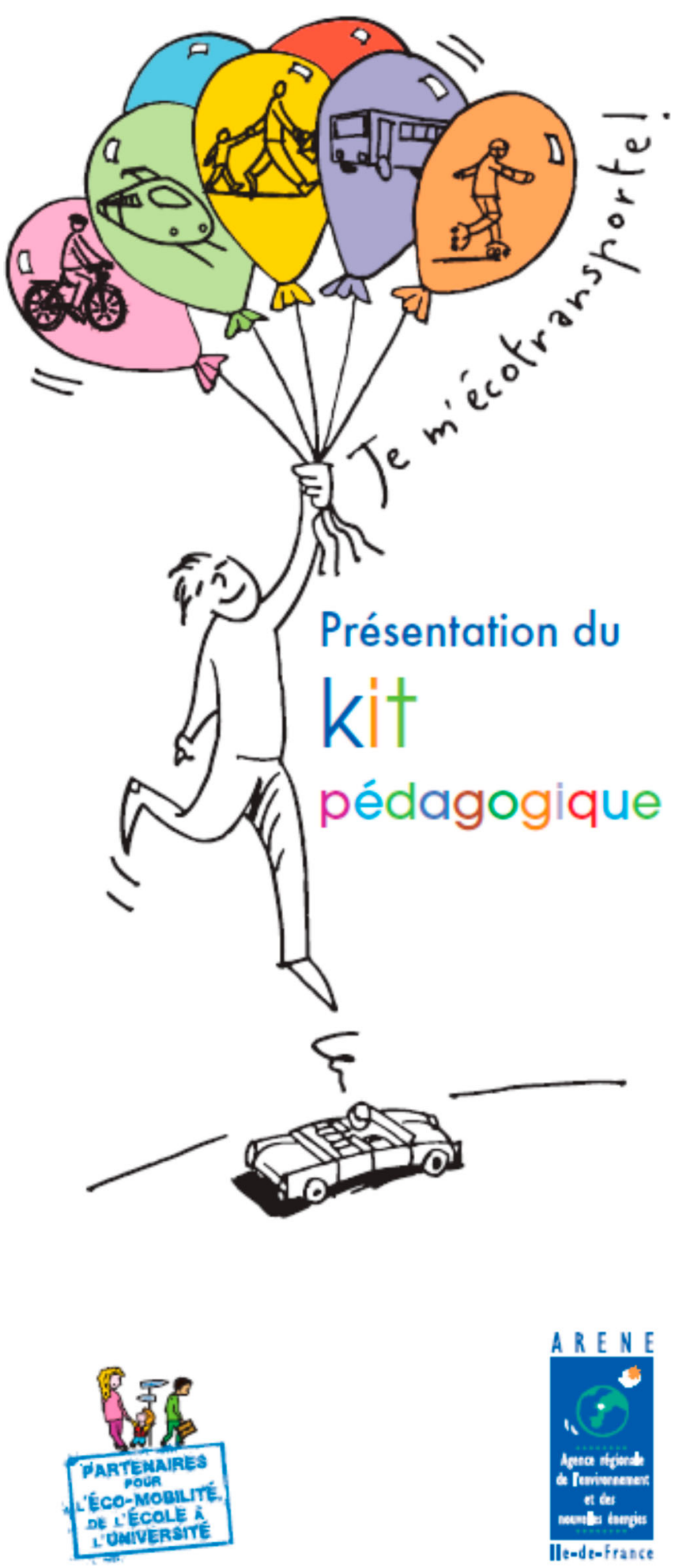

Fig. 2. Pedagogical green games in the management of sustainable mobility issues. Source: ARENE (Agence Régionale de l'Environnement et des Nouvelles Energies d'Ile de France - Ile de France Regional Agency for the Environment and New Energies), "kit pédagogique. Je m'éco-transporte" ('Educational kit. I use eco-transportation'), http://www.areneidf.org (CARENE-KERWAN. 
citizens that the governmental action is right, whether by the State, local authorities or public actors. Using pedagogy, the point is to encourage citizens to accept governmental decisions and to convince them that the policy choices are well founded.

The paradigms, instruments and communication used in policies in favour of safe and sustainable mobility thus put forward neoliberal rationality that makes individual behaviours the key to solving public problems, seeking to normalize these individual behaviours by encouraging them to align themselves with a cost-benefit kind of rational economic calculation, using pedagogy to convince them that this rationality is well founded. While the challenges of sustainable mobility are on the agenda of all urban governments, this neoliberal rationality has depoliticized these issues. Coupling this neoliberal rationality with moral injunctions completes this depoliticization process.

\section{VIRTUE, MORALITY AND NOBLE CAUSES. THE NEOHYGIENIST RATIONALITY OF SAFE AND SUSTAINABLE URBAN TRANSPORT POLICIES}

Looking into the deactivation of liberal democracies ('de-democratization') and seeking to understand its causes, Brown has put forward the theory that the basics of the project for shaping the political subject upon which liberal democracy is founded have now been undermined by inserting morality into politics. For her, this temptation towards moralization in politics is a global political fact that concerns all Western societies and can take of different forms depending on the national contexts in which it occurs (BROwn, 2007).

Pursuing this line of study opened up by Brown, and in response to French studies seeking to distribute her theories in France (JEANPIERRE, 2007), we have sought to characterize the moral fabric of sustainable urban transport policies. While the American situation is marked by the resurgence of a neo-conservative rationality that takes on a religious form mobilizing Christian morality, the moral injunction in France is the work of secular actors and institutions. A catechism of the Republic permeates public action, ordering the citizens to adopt virtuous behaviours in the name of noble causes.

\section{The 'noble causes' of urban transport policies: Sustainability, safety and health}

Since the middle of the 1990s, three grand causes have been evoked to justify urban transport and travel policies: sustainability, health and safety.

Sustainability and public health are two grand causes mobilized jointly in urban transport and travel policies to justify public intervention in favour of improving air quality and promoting active mobility. In France, in the 1990s, the Urban Travel Plans in the Law on Air and Rational Energy Use (LAURE Law) provided an opportunity to put the promotion of alternatives to the automobile on urban government agendas. The objective of improving air quality gave rise the injunction to 'move differently', that is, 'move without polluting', leave your 'car in the garage' and take public transport or 'soft' travel modes. The term 'soft modes' has been adopted to designate travel modes that are not aggressive for the city, urban life and the environment, mainly walking and bicycles.

Under the effects of a rise in concerns for public health, 'soft modes' have become 'active modes' and, with this, pedestrians and cyclists, who were already considered to be virtuous and responsible, have a way to stay healthy by engaging in regular physical activity. Adopting soft modes that have become active is presented not only as a travel mode that helps to improve air quality, but also as an effective way of combatting obesity and its consequences on the population's health. Thanks to active modes, the city can be freed of automobiles and their nuisance. In promoting active modes, public health win 
out on two fronts by reducing both pollution and the negative consequences of a sedentary lifestyle.

The second major moral register moral in urban transport and travel policies combines sustainability and safety. This is a bit more recent. In 2000, the Law on Solidarity and Urban Renewal (SRU Law) acknowledged the problem of the insecurity of soft modes. Pedestrians and cyclists are rightly considered as vulnerable users in cases of traffic accidents that put them into conflict with motor vehicles. ${ }^{5}$ To encourage walking and cycling, the SRU Law asserted that the first goal of Urban Travel Plans is 'to improve the safety of all travel, $[\ldots]$ notably by setting up an observatory for accidents involving at least one pedestrian or one cyclist'. ${ }^{6}$ By doing this, the challenges of road safety and sustainability mobility, which until then had been covered by different sector-based policies, became integrated into policies in favour of safe, sustainability mobility.

Historically, in France, road safety's emergence as a public problem is linked to publicizing authoritarian narratives with moralizing tones by the medical profession and the Church. In the context of strong automobile growth in the 1950s, doctors denounced the social cost of 'road slaughter', the leading cause of death among 16-24 year-olds. The Church rounded out the hygienist medical narrative by stressing the responsibility of drivers who were considered as guilty road murderers, with deviant behaviours (DECRETON, 1993). Here we can see the same process as the one described by Gusfield, who saw the construction of the 'drunk driving' argument in the United States as a communication challenge serving a moral order (GuSfield, 1981). Science and the law in the area of road safety show a world where moral responsibility is clear and where causes and effects in the area of road safety are only influenced by the driver's 'good' or 'bad' behaviour. This responsibility of the driver is therefore the target of public action.

Still today, this moralistic, monocausal vision of traffic accident production permeates road safety policies (REIGNER, 2005). It is diffused in the field of sustainable mobility through the challenge of safety for 'vulnerable users' and plays a role in expanding the scope of morality.

The 'noble' causes' of Urban Transport Policies (sustainability, health and safety) thus give rise to three moral injunctions: 'Move without Polluting' (Figure 3), 'Moving 30 Minutes a Day is Healthy' (Figure 4), and 'Move without Killing' (Figure 5). Legitimized by the mention of 'noble causes' such as preserving an acceptable environment for future generations as well as people's safety and health, these narratives appear to be presented naturally as being obvious, imposing 'the right way' of doing things, 'the right way' of behaving. But these narratives are not just narratives. They are the expression of a rationality that is translated into acts.

From the categorization of 'good' and 'bad' users to the selective organization of mobility in the city

This use of morality is accompanied by the categorization of 'good' and 'bad' users. This lays down an individual, psychological treatment of the challenges of mobility. This discursive register therefore is not just a narrative. It is mobilized to legitimize controls over traffic and to justify a selective organization of mobility for city traffic flows. This leads to expanding tools for monitoring and control, but also, more subtly, layouts of public spaces and road systems.

Monitoring and control technologies are widely used tools in policies that seek to regulate traffic in the city. Since the beginning of the 2000s, a twofold movement has been at work with increased controls and stiffer penalties (BONNET, 2012). This intensified repression is backed up by surveillance technologies, with cameras on the roads to 
$\square \square \square \square \square$

Bouger sans polluer, tout le monde y gagne!

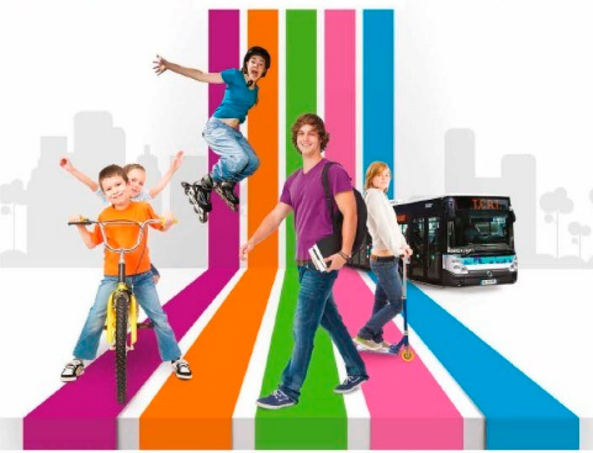

SEMAINE EUROPÉENNE

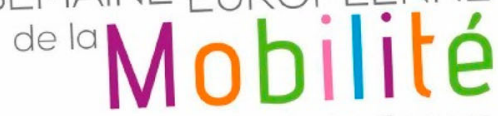
dans l'agglomération Troyenne
Du 16 au 22 septembre 2014

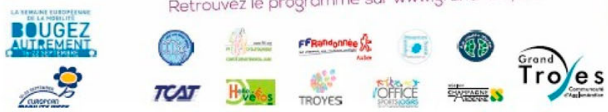
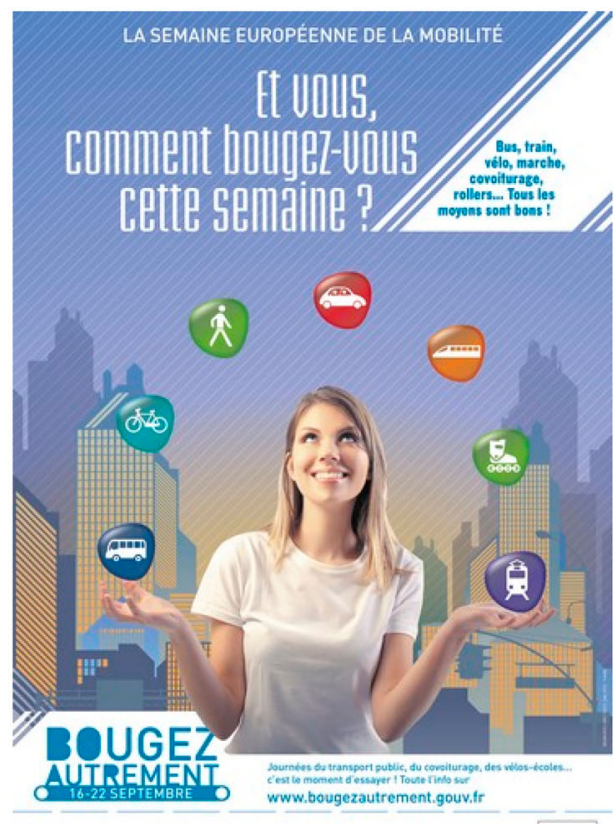

国

www bovgezautrement.gouvit

Fig. 3. Environmental injunction to 'Move without Polluting'. Sources: Communication campaign for 'European Mobility Week' 2014, http://www.grand-troyes.fr and www. bougezautrement.gouv.fr, Ministère de l'Ecologie et du Développement Durable.

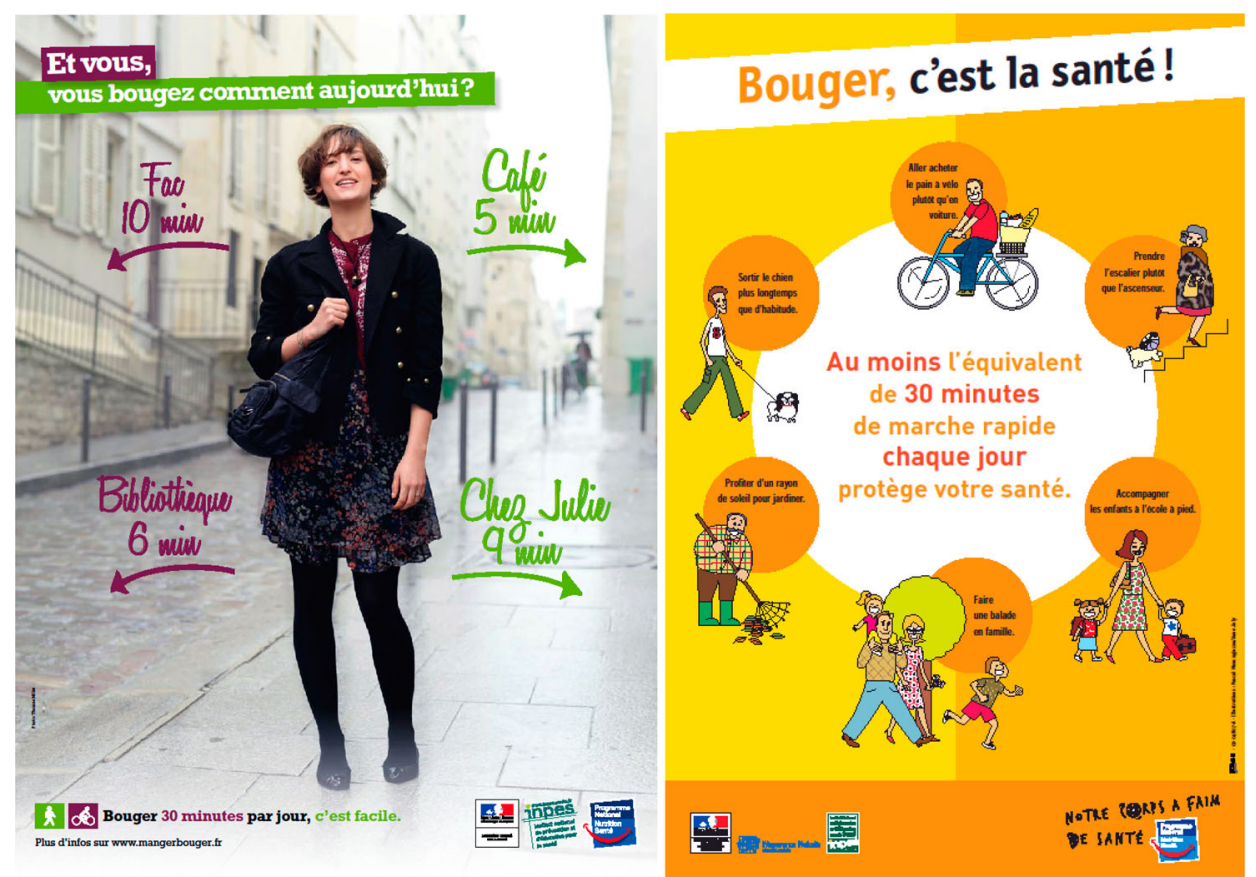

Fig. 4. Health injunction to 'Move 30 Minutes a Day'. Source: www.inpes.sante.fr. 

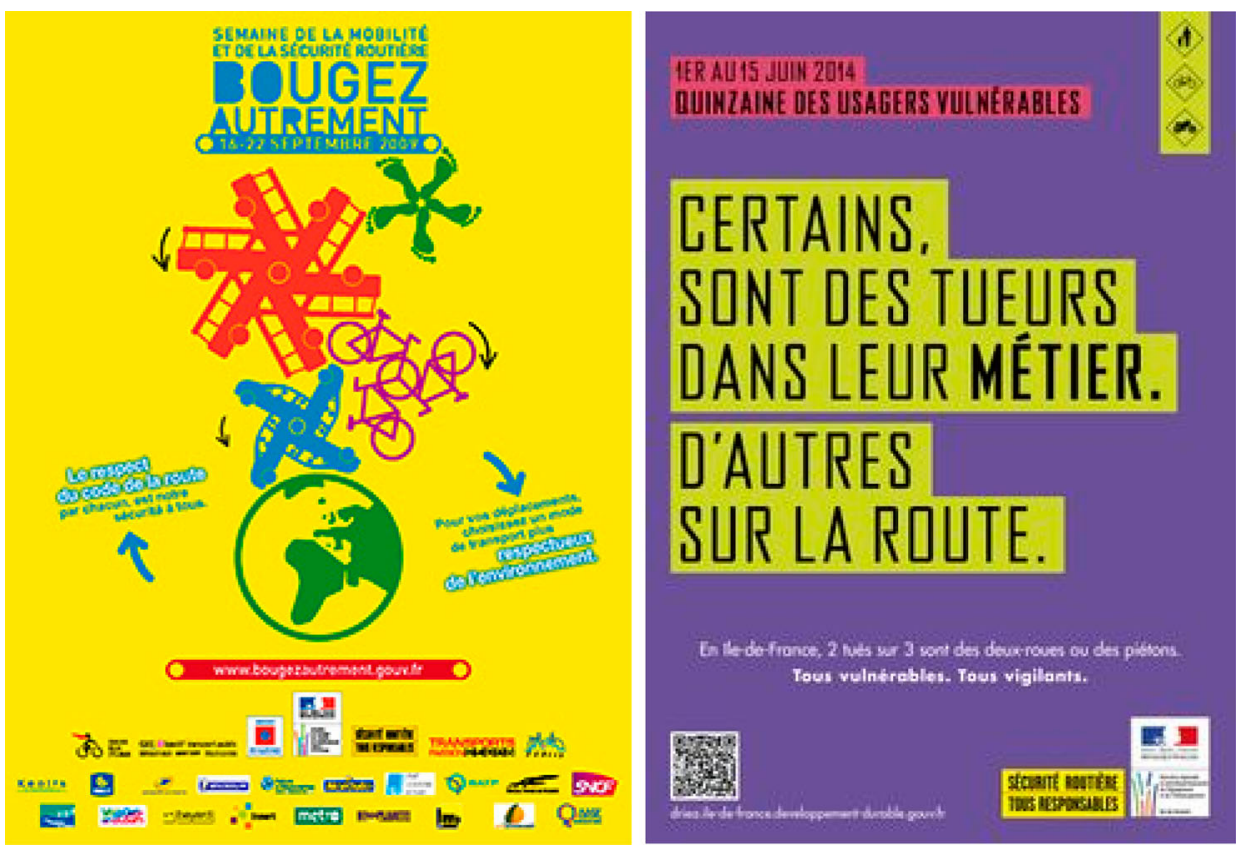

Fig. 5. Safety injunction to 'Move without Killing'. Sources: http://www.developpementdurable.gouv.fr/, Ministère de l'Ecologie et du Développement Durable and http://www.securiteroutiere-idf.fr/entreprise / (C) DRIEA-IF (Direction régionale et interdépartementale de l'équipement et de l'aménagement d'Ile-de-France) and DUFRESNE.

issue tickets for running red lights or driving in bus lanes, automatic radars to control speeds, parking metres that report non-payment for parking and more cameras for organizing restricted access to certain urban areas (perimeters of urban toll systems, semi-pedestrian areas). Furthermore, this technological expansion of controls is increasingly often combined with automated penalties.

But sorting uses and users can take on much more subtle forms. The layout of roads and public spaces, requalification project after requalification project, make possible such-and-such a use here and such-and-such other uses there. They notably make certain uses impossible and, by doing so, chase away users considered as being unvirtuous. The tools used to implement these policies often come with key adjectives such as green, citizen, eco-responsible, clean, civilized, soft or calm to qualify the road, the street, the neighbourhood, the square, the boulevard, etc. They all have one point in common - they seek to 'free the city of its nuisances'. This notably entails reducing the place of the automobile in cities. This consensual goal often only ends up reducing visibility, on the surface, of certain categories of automobile drivers in reduced urban perimeters, usually hyper-central areas that are historical and have heritage significance. Users are very finely sorted as needed, for example, for building an underground parking structure - which must be attractive, accessible and available to visitors-consumers - and to them alone - or a project for a pedestrian area - which has to be able to receive tourist buses. Access to the heritage section of a city is restricted with a fee (parking and urban tolls), which is among the most visible manifestations of the enclosure systems that make use of the toolbox applied to requalify the road system and public spaces. This way of regulating mobility in the city leads to organizing traffic to suggest who can move 
about in the different areas of the city. Operations for spatially sorting users are also operations for socially sorting users, and this coupling of spatial sorting and social sorting is particularly visible in the most strategic areas of cities.

\section{Neohygienism}

A neohygienist rationality prevails on the subject of implementing layout instruments which seek to restrict the automobile's presence through actions on the layout of public space. The notions of 'sharing the road system' and 'taking back the street' are presented by their promoters as layout tools for redistributing public space in a way that is less favourable to automobiles, thereby reducing air pollution, limiting road insecurity, creating 'user friendliness', 're-humanizing' the city by reducing speeds ('traffic calming' as it is now called), but also 'upgrading' city centres and 'revitalizing' their businesses. In other words, the automobile downgrades the city, and limiting its presence becomes a must for a dense, sustainable city. The objectives of restricted automobile access and greater urban quality are superposed. Concretely, these policies organize graduated management of automobile penetration into the city. The quality of the treatment of public spaces increases as one approaches the centre, which is supposed to be preserved from the automobile and its harmful effects.

These policies have a several points in common with the Natural Hygienist policies of the 19th century (FrIOUD, 2013). These came from the conjunction of the discourse on hygiene of the medical world and that of the bourgeoisie demanding cleaner cities. Natural Hygiene is a moral project which is part of the space and bodies in which hygiene and public salubrity, order and police are closely interlinked. Urban order, social control, the control of flows and movement in the city have always been a concern and an issue of power. Free, uncontrolled circulation of flows is seen as a factor of disorder and danger that the authorities have always tried to direct and plan. Thierry Oblet reminds us how the city police sought to regulate tensions between the social classes in the city by drawing a whole range of measures from urbanist practices for treating urban highways, which made it possible both to make the city exist as an economic force and to eliminate the risks of epidemics and revolutions (OBLET, 2005). As for Foucault, he showed the extent to which Natural Hygiene, which controls the social agent for his own good, by working more on norms than on the law, is the vector of normalization without limits, evacuating any alternative discourse. Present everywhere and at all times, it is based on micro-powers, produces discourse rather than repressing and encourages confession to identify the deviant (FOUCAULT, 1975).

If Natural Hygiene emerges with industrial capitalism, then neohygienism is its equivalent in working towards putting the post-industrial city in order. The new qualified urban middle classes, attracted by the social and spatial attributes of old centres, seem to have taken over from the industrial bourgeoisie and foster this process under the illusion that is the bearer of social innovation in a festive and companiable city (MATTHEY AND WaLther, 2005). The imagined neohygienist urbanity combines social mixing and density in clean, safe cities, renovated and upgraded, but above all, in which those who disturb this beautiful organization are summoned to be less visible by concentrating their presence in certain spaces in the city. The full range of resources deployed in cities largely calls upon the combined register of standing, safety and urban quality. The safe city, which is safe, clean, sustainable and compact, becomes a model to be followed, an answer to the question of urban disorder, providing an attractive environment for the middle and upper classes and controlling uncivil behaviours (HeLms et al., 2007; REIGNER et al., 2009). This ordering of the city is diffused in aspects that are increasingly 
numerous and varied. In a well-ordered public space, the street furniture is designed so that homeless people cannot lie down on the benches designed for public transport customers or on the edge of store windows that tourists frequently visit (PATE and ARGILLET, 2005). Municipal ordinances define perimeters, often neighbourhoods that are 'free from automobiles', in which begging and soliciting, wearing caps or riding skateboards are forbidden. Parking is organized so that commuters' cars, referred to as 'sitting cars', do not take up the parking places designed for visitors and consumers. Conduct is carefully regulated in public spaces by activating legal requirements and moral injunctions, often at the same time (Coleman, 2004, 2005).

How do we explain the diffusion of this neohygienist rationality, this moral project for governing people's conduct? The analysis of urban policies in favour of sustainable mobility leads us to say that this hygienist rationality makes it possible to move beyond and dissolve certain contradictions in the way the contemporary capitalist city works: moving beyond the contradictions by putting order into traffic and flows that are legitimized, dissolution through the depoliticization that this transmits.

\section{NEOHYGIENIST RATIONALITY: MOVING BEYOND AND DISSOL- VING CONTRADICTIONS IN THE CONTEMPORARY CAPITALIST CITY}

Putting order into the flows to move beyond the contradictions between capitalist city traffic flows and the sustainable city

The challenge of controlling flows and traffic in cities is renewed when contemporary capitalism speeds up and demands free flows on the one hand, and exacerbates competition between cities to attract investment - large corporations, prosperous, solvent populations, consumers and tourists, on the other. The selective organization of mobility in the city through urban planning and transports and travel safety policies is a particularly prominent challenge in contemporary urban policies.

Clearly, urban planning for transport and travel serves urban attractiveness by optimized traffic flows in cities. The equation to be solved is the following: how can fast, high-performance flows of goods, services and people considered to be necessary and inherent to running a metropolis cohabit with the slower flows of urban pedestrians associated with the identity, image and quality of historic European cities? This equation is solved using differentiating treatments of public spaces and implementing operations that classify and specialize urban spaces.

On the one hand, an attractive metropolis has to be well connected to transport networks and quickly accessible. For this, the metropolitan territory must attract high-speed hubs such as airports, high-speed train stations and motorway interchanges. For the entire urban area, a high-performance road network that can handle heavy flows without congestion is needed. This results in projects for large infrastructures dedicated to automobiles, ensuring high-speed travel. At the same time, to be attractive and have a good ranking among the 'most livable cities', a city also has to be a privileged place for pedestrian shoppers, tourists and 'soft' mobility access. In France today, this gives rise to restricted automobile flows in certain urban spaces by layouts that mobilize the semantics of urban quality, limiting the possibilities of city automobile use (shared road systems, segregated lanes for public transport, limited parking areas, etc.) or aimed at reducing speed (so-called traffic calming zones).

In practice, this desire for optimized flows and mobility is resolved by sharing the territory: the historic city centres and secondary centres are protected from automobiles, while the urban periphery has the large, high-performance road infrastructures and 
major hubs. Regulating the place of the automobile is thus an answer to sharing the territory horizontally and gradually from the centre to the periphery. Then there is the vertical sharing of the territory: on the surface, the road networks give a large share of the space to non-motorized travel modes; they are laid out in urban boulevards with bus lanes and cycling lanes. Underground, tunnels grow longer, expressways are dug out and underground parking structures are multiplying. Cars continue to cross the city centre, but they are hidden, buried.

As a technical object which may be considered secondary, parking policy gives a good example of the selection made in planning urban travel. Alongside these policies, which seek to restrict the presence of automobiles by acting on the layout of public space, different kinds of users are identified and sorted. Fees are tools for implementing this sorting. Restricted automobile access to the city centre is organized with graduated parking pricing that becomes more expensive the closer one gets to the centre, whether underground parking or surface parking. Furthermore, surface parking is rationed in terms of quantity and the square metres dedicated to automobile parking are taken over to be transformed into space for urban pedestrian practices and non-motorized travel modes. What is striking in this example of parking policies is that the object of the battle is not automobiles, all automobiles, but certain types of use. Urban operations to enhance the commercial attractiveness of city centres are always accompanied by an improvement in possibilities for parking, often underground car parks. This automobile accessibility is considered by local stakeholders as an instrument which strongly determines the dynamism and attractiveness of urban spaces, including central ones. The priority target of this policy is the fight against 'sitting cars', meaning cars that have a low rotation rate. These may be cars belonging to residents who do not have private parking spaces and do not necessarily use the car during the day and occupy parking places that urban authorities want to keep open for visitors, tourists and customers' cars. This could also include suburban commuters' cars, parked in the city for the entire working day, the commuters being strongly encouraged to carpool and to use peripheral car parks. Present policies oppose the car only in certain spaces and for certain uses and oblige only those who do not have the means to obtain preferential treatment.

Thus, while urban planning for transport and travel makes headlines with sustainable mobility, contemporary transport and travel do not seek to reduce polluting modes of travel overall, but rather to direct them onto bypass road infrastructures to reduce their negative impacts on the city's main sites. Automobile pollution (noise, congestion, air pollution and insecurity) is considered as a risk that must be reduced and eliminated from certain strategic, symbolic urban micro-territories. These urban policies are at the service of an agenda dominating them, with the aim of ensuring an urban climate favourable to business and trade (BRENNER, 2004). There is no doubt that highlighting the "quality of life' in historic, picturesque, heritage city centres partly meets the need to enhance an urban identity, which is also a comparative advantage that European cities use and abuse, the perfect counter-model to the American XXL metropolis or the emerging world.

This model of traffic organization founded on differentiated and graduated treatments of public space between the centre and the outskirts does not, however, give rise to debate. It asserts itself as an obvious technical and depoliticized response.

\section{Morality as an arm for dissolving conflicts. Depoliticization and desactivation of democracy}

Although they involve numerous actors with differing interests, the operations of urban travel planning give rise to the production of a remarkable consensus. Despite the participative procedures of the public debate that accompany the drafting of Urban Travel 
Plans, the voices of discord are fragmented and rarely publicized. The room for debate is small and the procedure is formatted, consultations are reduced to the prerequisite of the social acceptability of the decisions (FRERE, 2011). Those actors who could present alternative views, notably relative to the social challenges of mobility, are almost systematically absent (PAulhiac-SHerRer, 2011). The forums for debate do feature pluralism, but this pluralism tends only to welcome 'responsible partners' (CROUCH, 2004). Conflicts therefore have every chance of being nipped in the bud. Sometimes they come up in road discussions on the periphery of Urban Travel Plans - projects for completing urban ring roads whose missing sections require digging costly tunnels in some places (Grenoble), in others they cross prestigious vineyards (Bordeaux). But the moral grandeur of their ecological and sanitary justifications confers an unquestionable status to the most central projects associated with promoting sustainable mobility. It dissolves any opposition - projects aimed at promoting soft modes, trams and self-service bicycles may give rise to public debate procedures, they are surrounded with such an aura of virtue that few people dare question the legitimacy of the layout of a tram line, object to the cost of urban-quality cobblestones or ask about the contract that gives the free-service bicycle contract to the JC Decaux company. ${ }^{7}$ Consensus and free conformation assert themselves.

By eliminating the possibility of debate as to the soundness of the chains of arguments linking the problems and the solutions, these registers of justification limit the debate as to the efficacy of the policies. It is then no surprise that the conditions for success or failure of public action are seen in terms of the responsibility of 'good' or 'bad' individual behaviour. This depoliticization of the issues of urban quality thus limits the selective management of flows in the city to technical and operational matters on the one hand, and to communication and pedagogy on the other.

Alternative frameworks exist, however, but the contemporary use of morality complicates their expression. Indeed, criticizing these public policies puts you on the side of those who want more deaths on the road, more pollution, and a degraded environment for future generations.

Internationally, there exists a science of the safety of complex systems, notably road systems. ${ }^{8}$ Within this scientific community, accidents are the consequence of dysfunctional situations in the interaction between a vehicle, an infrastructure/an environment and users in which the user is just the regulator confronted with the complexity of the situations. Focusing the treatment of the road safety problem on human failure, on a deliberate disobedience of the rules, on an act of delinquency, is scientifically considered nonsense. According to these approaches, drivers do not commit violations but rather errors that are the consequence of non-perception or a poor interpretation of driving situations. So the man-vehicle-environment system should be organized more based on managing errors and a tolerance for margins of error. The vehicle is thus a decisive factor in the accident, and especially its consequences and its severity: improving braking performances, ergonomics, materials, equipment and bridling the engine could improve safety. Likewise, the infrastructure and its layouts are also decisive factors in accidents. Recently, the Swedes went so far as to state that infrastructure designers are the first people responsible for traffic accidents. It is up to them to design the ergonomics of a traffic system adapted to human capacities and to avoid confusing drivers by putting them into overly complex, hard to understand situations (LIE and Tingvall, 2002). This view of road insecurity gave rise to the road layout policies developed in the Netherlands in the 1970s, then experimented in all European countries in the 1980s. Their assessment has shown that they provide significant, sustainable gains in safety (CETUR, 1990, 1994). And yet, despite these experiments, this public problem is 
predominantly framed as a direct causal link between the accident and drivers' performances, on a backdrop of condemning bad behaviours that alter these performances:

The role of specific makes of vehicles in auto accidents, the implications of various building plans and materials, the possibility of alternative forms of transportation, the costs of mobility in auto travel, or any widespread movement to lower auto fatalities by means other than influencing driver performance is absent from the news accounts and major legislation. (GuSFIELD, 1981, p. 44)

'Common law and legislation present drinking-driving as the paradigm, the myth and model of what is fearful and condemnable' (Gusfield, 1981, p. 144).

Alternative discourses also exist in the area of sustainable mobility, criticizing the foundations of contemporary policies. Firstly, the emphasis put on individual responsibility and the relevance of the 'free modal choice' paradigm is disputed. This way of viewing the question of the transport mode on the individual level presupposes that individuals have a choice and can arbitrate between several alternatives. Now, the 'free choice' paradigm would be obsolete once the rate of household automobile ownership reaches $80 \%$ and the automobile exercises a radical monopoly compared with other travel modes. An automobile system is at work. The city and contemporary lifestyles have been and are shaped by this system. Thus,

it is as if competition has been skewered against non-automobile modes through their difficulty in ensuring travel that is overly long and overly dispersed in time and space. [...] This situation obviously results in an absence of real choice between modes, i.e. a quasi-obligation to use a car, a form of dependency. (Dupuy, 2006, p. 39)

But above and beyond the question of the (in)effectiveness of public policies based on the principle of 'free modal choice', there is also the question of the legitimacy of public action that ignores the social stakes and determinants of mobility. The fragmentation of the territories crossed in everyday life (which entails crossing ever greater distances) and the fragmentation of work (involuntary part time work, temporary job placements, insecure contracts and staggered shifts) considerably restrict individuals' flexibility, especially for the most fragile among us (Le Breton, 2005; Orfeuil, 2010). Furthermore, automobile use is the most discriminating factor in inequality in the area of travel, and household income is decisive in explaining this unequal access to private cars (Claisse, 2002; Dupuy et al., 2002). By stressing individual responsibility for eco-mobility, this public problem is not properly taken into account in a complex social structure.

Thus, policies in favour of safe, sustainable mobility give rise to strong media coverage at the same time as there is a relative absence of political debate as to how to frame this problem. Although these challenges are on the agendas of all urban governments, it should be pointed out that a consensus predominates over how they are handled. Objections are suppressed by moralizing and depoliticizing the challenges they give rise to.

\section{CONCLUSION}

The use of morality in politics, expressed through neohygienism in France today, is a powerful democratic anesthetic feeding what others have called post-political urban management (SwYNGEDOUw, 2005), the post-democratic evolution of urban societies (Crouch, 2004) or de-democratization (Brown, 2003). Indeed, we agree with the observation put forward by Swyngedouw that there is a depoliticization of the way in which contemporary environmental problems and their treatment are framed, the 
narrowness of the discussions, and the inexistence of alternative socio-ecological trajectories. We also concur with the analyses by Crouch when he asserts that disagreement is possible so long as it stays within the framework of the general consensus model put forward by the élites, and that pluralistic inclusion in urban governance is possible so long as one is considered a 'responsible partner', which tends to exclude the working classes.

Lastly, we share with Brown the intuition that this de-democratization process in Western societies feeds on using morality in politics insofar as it is used to depoliticize social problems, to transfer responsibility to the individual level and to gen the citizen-customer-consumer to accept a high level of governance and authority. In this article, we have sought to characterize this use of morality in France, to identify its content, its forms and its effects based on a field of public action.

There is no doubt that this field of research needs additional studies mobilizing international comparisons in various sectors of public action. Nor is there any doubt that it is urgent for us to re-politicize many public policy issues in order to reenchant the world through means other than morality: 'You cannot respond to a Gospel with another Gospel' (JEANPIERRE, 2007, p. 30). Researchers in the social sciences should certainly be able to play a role in this undertaking to publicize alternative framings and to re-politicize the issues to make other narratives and other framings of public problems possible, to bring what is new and impossible into the field of public debate.

Acknowledgments - For critical comments and astute suggestions on this article, the author would like to thank Gilles Pinson as well as TPG's reviewers. The research for this paper was founded by the French National Research Agency (ANR).

\section{DISCLOSURE STATEMENT}

No potential conflict of interest was reported by the author.

\section{NOTES}

1. This controversy was the subject of the international conference 'The Neoliberal City: a Credible Thesis', held in Lyon-Saint Etienne on 13 and 14 September 2012, and from which this article comes.

2. Orientation Law on Internal Transports (LOTI - Loi d'Orientation sur les Transports Intérieurs), Law 82-1153, 30 December 1982. The LOTI law created the Urban Travel Plans. The aim was to promote an urban transport system in favor of public transport.

3. Law on the Air and Rational Energy Use (LAURE - Loi sur l'Air et l'Utilisation Rationnelle de l'Energie), Law 96-1236, 30 December 1996, and Law on Solidarity and Urban Renewal (SRU - Loi Relative à la Solidarité et au Renouvellement Urbains), Law 2000-1208, 13 December 2000. The LAURE law reactivated Urban Travel Plans to play an ecological and public health role. Towns of more than 100,000 inhabitants had to work out their own sustainable mobility management.

4. Since 2010, the regulation of automobile access to the city through fees is now possible in France by the setting up of urban toll systems. Law No. 2010-788 of 12 July 2010 containing the national commitment to the environment, JORF No. 0160 of 13 July 2010.

5. Bicycles and walking are travel methods with a risk of injury per kilometer that is five to ten times higher than for automobiles (ELVIK AND VAA, 2004).

6. Law on Solidarity and Urban Renewal (SRU - Loi Relative à la Solidarité et au Renouvellement Urbains), Law 2000-1208, 13 December 2000, article 96.

7. This is an interesting example. The Parisian self-service bicycle system, "Vélib", has been the subject of lively controversies between Paris City Hall (Socialist) and certain elected municipal 
officials from the Verts party (Greens). The latter came out against a costly system that serves the privatization of public spaces and the advertising market. The Verts nonetheless decided not to vote against the "Velib" project. Discussion with these elected officials testified that this alignment was adopted given the difficulty of accepting to cast a vote that would not be understood and interpreted as being against the use of bicycles in the city (TIRONI, 2011).

8. The reference publications are: Safety Science, Accident Analysis and Prevention, and the Journal of Safety Research.

\section{REFERENCES}

Bonnet F. (2012) Contrôler les populations par l'espace? Prévention situationnelle et vidéosurveillance dans les gares et les centres commerciaux, Politix 97(1), 25-46.

BRAwley L. (2009) The practice of spatial justice in crisis, Justice spatiale|Spatial Justice 1. (available at: http://www.jssj.org/article/la-pratique-de-la-justice-spatiale-en-crise-2/) (accessed on September 2009)

Brenner N. (2004) New State Spaces: Urban Governance and the Rescaling of Statehood. Oxford University Press, Oxford.

Brown W. (2003) Neoliberalism and the end of liberal democracy, Theory \& Event, 7(1), 37-59.

BRown W. (2007) Les habits neufs de la politique mondiale. Néolibéralisme et néo-conservatisme, Les prairies ordinaires.

Cetur (1990) Ville plus sûre, quartiers sans accidents, Savoir-faire et techniques. Ministère de l'équipement.

Cetur (1994) Ville plus sûre, quartiers sans accidents, Réalisations, évaluations. Ministère de l'équipement.

Claisse G. (2002) Inégalités de déplacement et équité sociale : la donne. PREDIT/PUCA, LET/ ENTPE.

Coleman R. (2004) Reclaiming the streets: Closed circuit television, neoliberalism and the mystification of social divisions in Liverpool, UK, Surveillance \& Society 2, 293-309.

Coleman R. (2005) Surveillance in the city: Primary definition and urban spatial order, Crime Media Culture 1(2), 131-148.

Crouch C. (2004) Post-Democracy. Polity Press, Cambridge.

Dardot P. and Laval C. (2009) La nouvelle raison du monde. Essai sur la société néolibérale. La Découverte, Paris.

Decreton S. (1993) Archéologie d'une politique publique, le cas de la sécurité routière, Les Cahiers de la Sécurité Intérieure, 11, 225-245.

DuPuY G. (2002) La pauvreté entre assignation territoriale et dépendance automobile: comparaison FranceRoyaume-Uni. PREDIT/ PUCA, Université de Paris X, LATTS/ENPC, Université de Manchester.

Dupuy G (2006) La dépendance à l'égard de l'automobile. La documentation française, Prédit.

Elvik R. and VaA T. (Eds.). (2004) The Handbook of Road Safety Measures. Elsevier, Amsterdam.

Foucault M. (1975) Surveiller et punir: naissance de la prison. Gallimard, Paris.

Foucault M. (1994) La "gouvernementalité", Dits et Ecrits III (1976-1979). Gallimard, Paris, 635657.

Françors B. and Neveu E. (1999) Pour une sociologie des espaces publics contemporains, in Françors B. and Neveu E. (Eds) Espaces publics mosaïques. Acteurs, arènes et rhétoriques des débats publics contemporains, pp. 13-58. Presses Universitaires de Rennes, Rennes.

Frere S. (2011) Développement urbain durable et démocratie participative dans l'agglomération lilloise: une transformation des rapports entre politique et société?, in BEAL V., GAUTHIER M. and Pinson G. (Eds) Le développement durable changera-t-il la ville? Le regard des sciences sociales, pp. 105-121. Publications de l'Université de Saint Etienne.

Frioud S. (2013) Les batailles de l'hygiène. Villes et environnement de Pasteur aux Trente Glorieuses. Presses Universitaires de France, Paris.

GARAPON A. (2008) Un nouveau modèle de justice: efficacité, acteur stratégique, sécurité, Esprit 11, 98-122. 
Gusfield J. (1981) Drinking Driving and the Symbolic Order, the Culture of Public Problems. The University Press, Chicago, IL.

Helms G., AtKinson R. and Mac Leod G. (2007) Securing the city: Urban renaissance, policing and social regulation, European urban and regional studies 14(4), 267-276.

Hibou B. (2012) La bureaucratisation du monde à l'ère néolibérale. La Découverte, Paris.

Jaffe R., Klaufus C. and Colombijn F. (2012) Mobilities and mobilizations of the urban poors, International Journal of Urban and Regional Research 36(4), 643-654.

JeAnPIERre L. (2007) Qui a éteint la démocratie ?, in Brown W. Les habits neufs de la politique mondiale. Néolibéralisme et néo-conservatisme, pp. 5-34. Les prairies ordinaires, Paris.

Kazepov Y. (Eds.). (2005) Cities of Europe. Changing Contexts, Local Arrangements, and the Challenge to Urban Cohesion. Blackwell, Oxford.

Le Breton E. (2005) Bouger pour s'en sortir, mobilité quotidienne et intégration sociale. Armand Colin, Paris.

LE GALÈs P. (2003) Le retour des villes européennes. Sociétés urbaines, mondialisation, gouvernement et gouvernance. Presses de Sciences Po, Paris.

Lie A. and Tingvall C. (2002) La 'vision zéro' suédoise, Annales des Ponts et Chaussées 2002(101), $24-30$.

Lorrain D. (2002) Capitalismes urbains. Des modèles européens en compétition, L'année de la régulation, 6. Presses de Sciences Po, Paris.

Matthey L. and Walther O. (2005) Un «nouvel hygiénisme "Le bruit, l'odeur et l'émergence d'une new middle class, Articulo-Jounal of Urban Research 1. (available at: http://articulo.revues. org/931) (accessed on 25 July 2012)

Neveu E. (2001) Une société de communication. Montchrestien, Paris.

Oblet T. (2005) Gouverner la ville. Les voies urbaines de la démocratie moderne. Puf, Paris.

Orfeuil J. P. (2010) La mobilité, nouvelle question sociale? SociologieS.

Pate G. and Argillet S. (2005) Bancs publics'. Regard sociologique sur l'ordinaire des espaces urbains, Actes de la Recherche en Sciences Sociales 4(159), 117-118.

Paulhiac-Scherrer F. (2011) Les politiques de mobilité urbaine durable à la recherche de l'équité sociale : le rôle du débat public dans les PDU, in Beal V., Gauthier M. and PINSON G. (Eds) Le développement durable changera-t-il la ville? Le regard des sciences sociales, pp. 277-297. Publications de l'Université de Saint Etienne.

PAutARD E. (2015) La rhétorique pédagogique au service de l'acceptabilité sociale. Le verdissement des conduites individuelles en question, in BOISSONADE J. (Ed) La ville durable controversée. Les dynamiques urbaines dans le mouvement critique, pp. 106-139. Editions Petra, Paris.

Peck J. and Tickell A. (2002) Neoliberalizing Space, Antipode 34(3), 380-404.

PINSON G. (2009) Gouverner la ville par projet. Urbanisme et gouvernance des villes européennes. Presses de Sciences Po, Paris.

Préteceille E. (2009) La ségrégation ethno-raciale a-t-elle augmenté dans la métropole parisienne ?, Revue française de sociologie 50(3), 489-519.

Reigner H. (2005) L'idéologie anonyme d'un objet dépolitisé: la sécurité routière, Sciences de la Société 63, 125-143.

Reigner H. (2012) Le droit au transport: angle mort des politiques locales de transport et de déplacements durables, in Transport et politiques locales de déplacement, pp. 197-209. Droit et Gestion des collectivités territoriales 2012, GRALE-CNRS, Editions du Moniteur.

ReIGNER H. (2013) Sous les pavés de la qualité urbaine. Gouvernement des territoires, gouvernement des conduites et formes renouvelées de la domination dans la ville néohygiéniste, Mémoire d'Habilitation à Diriger des Recherches. Sciences Po, Paris, 17 juin.

Reigner H., Brenac T. and Hernandez F. (2013) Nouvelles idéologies urbaines. Dictionnaire critique de la ville mobile, verte et sûre. collection "Espace et territoires ", Presses Universitaires de Rennes, Rennes.

Reigner H., Hernandez F. and Brenac T. (2009) Circuler dans la ville sûre et durable : des politiques publiques contemporaines ambiguës, consensuelles et insoutenables, Métropoles $\mathbf{5}$. (available at: https://metropoles.revues.org/3808) (accessed on April 2009).

SAsSEn S. (2009) La globalisation. Une sociologie. Gallimard, Paris. 
Sheller M. and Urry J. (2006) The new mobilities paradigm, Environnement and planning $A 38$ (2), 207-226.

Smith N. (1996) The New Urban Frontier: Gentrification and the Revanchist City. Routledge, London.

Storper M. and Scott A. J. (2006) Régions, mondialisation et développement, Géographie, Economie, Société 2, 169-193.

SWYNGEDOUW E. (2005) The antinomies of the postpolitical city: In search of a democratic politics of environmental production, International Journal of Urban and Regional Research 33(3), 601620.

Tironi M. (2011) Comment décrire les infrastructures de vélo en libre-serviceLa mise en œuvre controversée du dispositif Vélib' parisien, CSI working papers series $\mathbf{0 2 2}$. (available at: http:// www.csi.mines-paristech.fr/working-papers/WP/WP_CSI_022.pdf) (accessed on April 2012) 